\title{
The Revival of Spanish Through Hispano-Filipino Literature in the Philippines
}

\author{
Jinmei Chen* \\ Faculty of Foreign Studies, Beijing Language and Culture University, Beijing, China \\ *Corresponding author. Email: violetacjm@outlook.com
}

\begin{abstract}
In this paper, we focus on another form of Spanish's survival within Filipino culture, Hispano-Filipino literature, and discuss whether it is possible to revitalize the Spanish in the Philippines through the existence of Hispano-Filipino literature, its teaching, and its spread.
\end{abstract}

Keywords: Spanish, the Philippines, Hispano-Filipino literature, Institute Cervante.

\section{INTRODUCTION}

Spanish, the second most spoken language in the world in terms of native speakers [1], has played an important role in Philippine history since its colonization by Spain in the $16^{\text {th }}$ century. It is obvious that Spanish's importance in the Philippines is related to its history of colonization. With the arrival of the Spaniards led by Fernando de Magallanes in 1521, the Philippines became a Spanish colony. In terms of governance, this archipelago belonged to the Viceroyalty of New Spain (Virreinato de la Nueva España), whose capital was located where the current Mexico City is, while it responded directly to the Peninsular metropolis of Spain. The Spanish influence on the Philippines can be perceived in many aspects: the name of the Philippines, which was given in honor of the Spanish Prince Felipe; the use of the "peso" as a monetary unit ("peso" is still commonly used in a great number of Hispanic countries); and especially the spread of the Catholic religion, which made the Philippines the only Catholic country in Asia. For a long time, Spanish remained as the administrative language in the Philippines, all of the legal codes were written in Spanish, and even during the Filipino literature's brilliant epoch, many literary works were written in Spanish. In another research, we have looked retrospectively at Spanish's historical importance, as well as its decline and apparent revival in the Philippines by analyzing some data [2]; this paper articulates some relevant studies on the Spanish in the Philippines and examines the revival of Spanish through Hispano-Filipino literature in this Asian archipelago.

\section{THE SPANISH LANGUAGE IN THE PHILIPPINES}

Regarding the Spanish in the Philippines, many valuable studies have been carried out. Among them, it is necessary to mention the linguist John M. Lipski, who has analyzed profoundly the contact between Spanish and local languages in the Philippines, particularly Philippine Creole Spanish like Chabacano. Lipski examined the reasons for the low profile of Chabacano in the Philippine linguistic consciousness, clarified some misunderstandings about Chabacano, and made several important explanations [3]. He also pointed out that among the strictly Spanish elements in Philippine Spanish; there are a number of Americanisms, most of which are clearly Mexican in origin [4]. In order to prove the legitimate usage of Chabacano, Lipski used late $19^{\text {th }}$ century literary texts as sources, such as words of Chabacano in José Rizal's El filibusterismo.

Keith Whinnom looked closely at the declining situation of Spanish in the Philippines through a comparison between Spanish and English in terms of status. He emphasized that "the major contribution of the Spaniards in the Philippines was that of the Spanish religious orders. The Philippines is a Catholic country." [5] He also argued that "the best of Filipino literature is written in that language [Spanish]." [6] He agreed with the favorite argument of the Hispanists, proposing that writers such as Rizal should be read by all Filipinos and pointed out the necessity to learn 
Spanish to appreciate this literature properly [7]. This inspired us to look at another possibility of the revival of Spanish: through Hispano-Filipino literature.

Belen Arguelles' study of "El estado presente de la enseñanza y aprendizaje del idioma español en Filipinas" has been a valuable reference for us to understand Philippine language teaching and language planification. In the study, Arguelles pointed out that once they had established governance, one of the first initiatives taken by the Spanish colonizers was to found schools for their children, and then, after the arrival of the missioners, the teaching of Spanish in the island began to take on religious overtones. That is to say, the educational objective during the Spaniards' governance was to prepare the young generations "en la virtud y en las letras," particularly, "la enseñanza primaria tenía básicamente un propósito religioso.” [8] After 1898, when the Philippines was ceded from Spain to the U.S., the Filipino educational system changed a lot [9]. This change, according to Arguelles, caused the younger generation to fail to understand Filipino history and learn "more about the history the American heroes, such as George Washington, Abraham Lincoln, Jefferson than the literary works and heroism of Rizal, Mabini, Del Pilar, López Jaena, los hermanos Luna and other patriots of the Malaya race." [10] In addition, under the educational policies oriented to science, the result was a negative effect, "por desgracia se ha hecho con perjuicio de los estudios humanísticos, inclusive del aprendizaje de idiomas, que se han ido eliminando gradualmente." [11] Arguelles also analyzed other problems, including lack of qualified teachers and good teaching materials. The most interesting observation made by Arguelles was to propose the foundation of an institute of Spanish dedicated to training teachers [12], from which we can make a connection with the later establishment of the Instituto Cervantes in the Philippines.

\section{CERVANTES INSTITUTE AND ITS PROMOTION OF SPANISH IN THE PHILIPPINES}

In 1994, three years after the foundation of the Cervantes Institute (Instituto Cervantes or IC for short) headquartered in Spain, the IC in Manila was established. According to the statistics published by the headquarters of the Instituto Cervantes, the IC of Manila in 1995 had 1014 students; in 2006 there were 2076 [13]; and for the year 2016-2017 there were 3000 students enrolled [14]. The doubling of the increase in the number of students in the IC in Manila makes it the one with the highest enrollment among all ICs in Asia. It is relevant to note that the IC in Manila is also in charge of the administration of IC Classrooms in Hanoi (Vietnam), Kuala Lumpur
(Malaysia), and Jakarta (Indonesia) [15]. The IC in Manila recently has built its second branch in Intramuros, while maintaining the current one in Makati [16].

The development of IC in Manila has promoted the learning of Spanish, but as we indicated in another paper, "A Study on the Development of Spanish in the Philippines," [17] the growth in the number of learners of Spanish at the IC does not change anything about the decline of academic teaching of Spanish in universities [18]. In addition, it is interesting to re-read news found in the year 2013 when we began this research; there was an official news article that announced the opening of new IC classrooms in Filipino cities like Zamboanga and Cebú [19]. It has turned out that the plan has not been realized as no further data information can be found in IC's official website about those cities.

An editorial project organized by IC of Manila deserves special mention: the collection entitled Clásicos Hispano-Filipinos that aims to recover works in Hispanic-Philippine literature. It demonstrates their efforts to try to recover the importance of the Spanish language, as stated in their website: "this seeks, in addition to preserving and vindicating the literary legacy of the last writers who expressed themselves in Spanish in the Philippines, to make known and make available to the public the works of a Spanish literature of remarkable historical and literary value." [20] At the same time, several IC's teachers have worked with Hispanists to advocate for the introduction of Hispano-Filipino literature into the Spanish teaching classroom. For instance, María Vanesa Afonso Pérez and Rosa Cámara Escriba confirm that the inclusion of Hispano-Filipino literature into the ELE (Español como Lengua Extranjera or Spanish as a second language) classroom can be an efficient method to motivate Philippine students and even Asian students [21]. Veronica González and María José Lobón, on the other hand, suggest a comparative combination between Spanish literature and Hispano-Filipino literature to achieve the teaching target of ELE [22].

\section{THE PROMOTION OF SPANISH THROUGH THE HISPANO-FILIPINO LITERATURE}

According to Luis Mariñas Otero, whose study on the imprint of the Spanish language on Philippine literature has been wildly cited, Hispano-Filipino literature began during the period of colonization, reaching its boom as a nationalist literature with the presence of the great literary figure José Rizal y Mercado (1861-1896). After experiencing its golden age during the $30 \mathrm{~s}$ and $40 \mathrm{~s}$, it has survived to today. As Mariñas Otero quoted from the politician M. Recto, 
Spanish culture and Spanish literature are an integral part of the Filipino soul, and one cannot destroy or dispense with it without destroying or tearing apart Philippine culture at the same time [23]. Mariñas Otero commented that Filipino literature in Spanish, unlike pre-Hispanic literature that was mostly from an oral tradition, has been characterized by the genre of prose. During the time of colonization, their themes were similar to those of Spanish romances, such as "the love between the Christian Prince and the Muslim Princess along with the conflicts and difficulties that this love causes." [24] In the nationalist period (18731903), patriotic poetry abounded. Many HispanoFilipino writers resorted to poems for summoning the people to maintain their Spanish importance and fight against America. This type of message can be read in José Rizal's poetry:

A nuestra España

Hijos amados

Bravos soldados

Del patrio hogar;

Ceñid de glorias

A nuestra España

En la campaña

De ignoto mar [25]
"To our Spain"

Beloved children

Brave soldiers

From the homeland

Gird on glories

To our Spain

In the campaign

From unknown sea"

(Our translation into English)

José Rizal played an important role for the Philippines similar to what José Martí meant for Cuba. The great impact of Rizal on Filipino progress was both literary and political. The compromised feature of Filipino literature in Spanish lasted until the Golden Age, which was from 1903 to 1942 , a period that coincided with the domination of United States. At that time, Spanish was the language used in the government, the Congress, the judiciary, and the Constituent Assembly of 1934. It was the language of high society and intellectuals, "it was the language of nationalism compared to English that represented foreign political power," and it was the time when "the best and most abundant of Philippine literature is written in Spanish." [26] From the 1940s to 1986, Hispano-Filipino literature experienced a decline, and after 1986 it only survived on sporadic production. The creation was so scarce that the publications had an episodic character and were a mere curiosity without resonance in a vast public forum and were incapable of affecting the literary production and cultural life of the country [27]. When reviewing the trajectory of Hispano-Filipino literature, one will realize that prose is abundant, but what is lacking is the novel, a determining genre to make literature lasting and attract more of the public. As a consequence, Filipino writers in Spanish always face the problem of a lack of readers due to a limited number of Spanish speakers in their own country.
This serious problem can be seen in the translation by the CI in Manila of the Hispano-Filipino Classics collection into indigenous languages. They published Recoged este voz "Gather This Voice" by Miguel Hérnandez with translations into seven native languages of the Philippines by some prominent Filipino poets. The repression of the creativity in Spanish-Philippine literature also is manifested in the abolition of the Zobel Prize. As a literary award, it was created in 1920 by Enrique Zobel de Ayala (18771943), Honorary Vice Consul of Spain, who was from one of the old Filipino families of Spanish origin. The establishment of the award was intended to promote the study of the Spanish language in the Philippines and to spread it in its literary form. Having positively motivated writers to promote literary production in Spanish for decades, it stopped functioning in 1966 [28].

Among the current sporadic productions of Hispano-Filipino literature, it is worth mentioning the author Edwin Agustín Lozada. Agustín Lozada was born in the Philippines and then moved to the United States. Currently he teaches Spanish language and literature in the U.S. and is the head of the foreign language department at Woodside High School in California. He began publishing in Spanish in 2001. For his fine style of poetic creation, he considers himself a new Rizal, and his work sueños anónimos ("anonymous dreams") was presented at the IC in Manila. His literary production reminds us that Spanish is still alive in the Philippines, and that the Philippines remain a Hispanic country where Spanish still serves as a means of communication and expression of ideas. However, in the interview the author was pessimistic about the current situation that the Spanish language suffers especially because of its abandonment by the authorities. When asked why he received an Anglo-Saxon education and decided to write in Spanish. He said: "I came to the United States when I was ten, but with a Filipino identity already quite established. I write in Spanish to contribute to Hispano-Filipino literature." [29] With regard to the decay of Hispano-Filipino literature and the study of Spanish in the Philippines, he criticized the decline and stated that if the number of Filipinos studying, speaking, and expressing themselves in Spanish does not increase, the Philippine Academy of Language and the Zobel Prize will no longer make sense and all these institutions will be relegated to the past [30].

\section{CONCLUSION}

Considering the language policy of the Philippine government (Spanish has been abolished as the official language) and the lack of interest in learning Spanish, only with the sporadic production of Hispano-Filipino literature will it be impossible to 
recover Spanish's historical power in the Philippines. The ex-director of the IC in Manila states that "the reality of Spanish today in the Philippines is not very different from that of other countries of the nonHispanic speaking world, even though it is special in nature given its historical past linked to Spain." [31] That is to say, the situation of Spanish there is precarious. To revitalize Spanish in the Philippines may simply be a beautiful dream, which, as Dan Maunteanu Colán says, is attributed in part to the romantic and nostalgic vision of the last Spanish colony and the heroism of soldiers in the Philippines, sometimes fed, artificially, by Spaniards themselves [32].

Thus, the revitalization of Spanish through Hispano-Filipino literature seems impossible. As José Rizal mentioned in his representative work $E l$ Filibusterismo (1891), "Spanish will never be the common language of this country; the mass of the people will never speak it, for the thoughts in their minds, and the feelings in their hearts cannot be expressed in that tongue. And you, what do you imagine you will accomplish with your Spanish, the few of you who continue to speak it? You will kill your originality, subordinate your minds to the minds of others, and instead of achieving liberty, you will make yourselves truly slaves!" [33]

\section{ACKNOWLEDGMENTS}

This research project is supported by Science Foundation of Beijing Language and Culture University (supported by "the Fundamental Research Funds for the Central Universities") (Projects Numbers: 20YJ020006 and 18YJ020020.

\section{REFERENCES}

[1] Instituto Cervantes. (2018). 577 milliones de personas hablan español, el 7,6\% de la población mundial [577 million people speak Spanish, 7.6\% of the world's population]. Retrieved on Dec. 4, 2020 from https://www.cervantes.es/sobre_instituto_cervant es/prensa/2018/noticias/np_presentacionanuario.htm

[2] J. M. Chen, A Study on the Development of Spanish in the Philippines. Proceedings of the Nineth Northeast Asia International Symposium on Language, Literature and Translation. 2020. In press.

[3] Lipski explained that Chabacano is a creole language rather than a mixed dialect of Spanish; Philippine Creole Spanish is but a relexification of a pan-Asian Portuguese-based creole." See J.M. Lipski, Chabacano/Spanish and the
Philippine linguistic identity. Invited keynote lecture, Conference "Shedding light on the Chabacano language," Manila, Philippines, October 2000. p3.

[4] Lipski, op.cit., p.7.

[5] K. Whinnom, Spanish in the Philippines, Journal of Oriental Studies, 1954, Vol. I, pp.129-194. See p.158.

[6] Whinnom, op.cit., p.161.

[7] Whinnom, op.cit., p.161.

[8] Arguelles mentioned that "el gobierno civil fue inaugurado el 4 de julio de 1901 ......A partir de esta fecha, los soldados americanos que habían sido empleados por los Estados Unidos fueron destinados para enseñar en diferentes partes de Filipinas." See B. Arguelles, El estado presente de la enseñanza y aprendizaje del idioma español en Filipinas, Presente y futuro de la lengua española, 1964, Vol. I, p.284.

[9] Arguelles, op.cit, p.283

[10] Arguelles, op.cit., p.284

[11] Arguelles, op.cit., p.287

[12] Arguelles, op.cit., p.288.

[13] J. Galván Guijo. (2006-2007). El español en Filipinas. El español en el mundo [Spanish in the Philippines. Spanish in the world]. 163-165. Retrieved on April. 10, 2020 from https://cvc.cervantes.es/lengua/anuario/anuario_0 6-07/lengua.htm

[14] Instituto Cervantes. (2016-2017). Memoria. Filipinas. Retrieved on Dec. 4, 2020 from https://www.cervantes.es/memoria_ic web/mem oria ic web 2016-2017/pdf/cervantes_20162017.pdf. See p.211.

[15] Instituto Cervantes. (2018-2019). Memoria. Filipinas. Retrieved on Dec. 4, 2020 from https://www.cervantes.es/memoria_ic_web/mem oria_ic_web_2018-2019/pdf/cervantes_20182019.pdf, p.243. 1

[16] C. De la Cruz, “The Spanish Cultural Center's Newest Outpost is an All-Blue Mansion in Intramuros" Retrieved on Dec. 5, 2020 from https://www.spot.ph/arts-culture/the-latest-artsculture/73706/instituto-cervantes-intramuros$\underline{\text { manila-a00171-20180509 }}$

[17] J.M. Chen, op.cit,

[18] There were 16,406 students learning Spanish at universities during the 1995-1996 period and only 12,466 students during the 2005-2006 
period. See Galván Guijo, J. (2006-2007). El español en Filipinas. El español en el mundo [Spanish in the Philippines. Spanish in the world]. 163-165. Retrieved on April. 10, 2020 from

https://cvc.cervantes.es/lengua/anuario/anuario_0 6-07/lengua.htm p.164.

[19] Instituto Cervantes. "El Instituto Cervantes abrirá tres aularios en Filipinas." Retrieved on Dec. 5, 2020 from https://www.cervantes.es/sobre_instituto_cervant es/prensa/2013/noticias/nuevos-aularios-filipinaspost.htm

[20] Manila. Cervantes. "Clásicos hispanofilipinos." Retrieved on Dec. 5, 2020 from https://manila.cervantes.es/es/cultura espanol/Cl asicos hispanofilipinos/Clasicos hispanofilipino $\underline{\text { s.htm }}$

[21] M.V. Afonso Pérez and R. C. Escriba. El uso de la literatura hispanofilipina en el aula de ELE. Retrieved on Dec.10, 2020 from https://cvc.cervantes.es/ensenanza/biblioteca_ele/ publicaciones_centros/pdf/manila_2009/19_aplic aciones_06.pdf. See p.309.

[22] V. González and M. J. Lobón. Dos orillas: literatura española e hispanofilipina en la clase de ELE. Retrieved on Dec.10, 2020 from https://cvc.cervantes.es/ensenanza/biblioteca_ele/ publicaciones_centros/pdf/manila_2011/29_aplic aciones 09.pdf

[23] Mariñas Otero, L. La literatura Filipina en castellano. Editora Nacional. Madrid. 1974. See p.16.

[24] Mariñas Otero, L., op.cit., See p.23.
[25] Mariñas Otero L., op.cit., See p.42.

[26] Mariñas Otero, L., op.cit., See p.51.

[27] G. Andrea. Una voz hispana de Filipinas: Edwin Agustín Lozada, Revista electrónica de estudios filológicos. Número13, 2007. Retrieved on April. 25, 2013 from https://www.um.es/tonosdigital/znum13/seccione s/estudios_K_lozada.htm

[28] Mariñas Otero, L., op.cit., See p.84.

[29] G. Andrea. op.cit.

[30] G. Andrea. op.cit.

[31] J. Galván Guijo, (2005). El español en...Filipinas. Cervantes [The Spanish in......the Philippines. Cervantes]. enero-febrero. 34-35. Retrieved on April. 10, 2020 from https://www.cervantes.es/imagenes/File/prensa/re vista/02/rc_elespanol_02.pdf

[32] D. Munteanu Colán, (2006). La situación actual del español en Filipinas [The current situation of Spanish in the Philippines]. LEA: Lingüística Española Actual, 28 (1), 75-90. See p.75.

[33] The original version in Spanish is the following: "el español nunca será lenguaje general en el país, el pueblo nunca lo hablará, porque las concepciones de su cerebro y los sentimientos de su corazón no tienen frases en ese idioma: cada pueblo tiene el suyo, como tiene su manera de sentir. ¿Qué vais a conseguir con el castellano, los pocos que lo habéis de hablar? ¿Matar vuestra originalidad, subordinar vuestros pensamientos a otros cerebros, y en vez de haceros libres, haceros verdaderamente esclavos?" See Whinnom, op. cit., p.154. 